\title{
Antropologiczna refleksja Mariana Przełęckiego
}

\author{
Magdalena Matusiak-Rojek \\ (Uniwersytet Łódzki, Wydział Nauk o Wychowaniu)
}

Marian Przełęcki o swoich zainteresowaniach badawczych pisał w następujących słowach:

Wśród moich prac filozoficznych wyróżnić można dwie główne grupy: prace logiczne i prace etyczne. Przedmiotem, którym zajmowałem się jako pracownik Zakładu Logiki, była oczywiście szeroko rozumiana logika. Etykę natomiast uprawiałem niezależnie od moich zajęć uniwersyteckich. To, co nazywam tu „logiką”, określić można bliżej jako metodologię nauk empirycznych. Jej głównym działem była logiczna semantyka języka teorii empirycznych. Reprezentowane przede mnie ujęcie tej semantyki polegało na zastosowaniu do niej aparatu pojęciowego logicznej teorii modeli ${ }^{1}$.

Warto jednak pamiętać, że oprócz tych dwóch kierunków potrafił on bardzo umiejętnie poruszać się także w ramach innych obszarów tematycznych. Na uwagę zasługują tu zwłaszcza jego rozważania o racjonalności wierzeń religijnych oraz o wartości poznawczej dzieł literackich i muzycznych. Antropologia pojawia się zaś w twórczości Przełęckiego w sposób epizodyczny, niemniej jednak są to rozważania bardzo cenne, warte wyeksplikowania, co przyjmuje sobie za cel niniejszy artykuł. Tekst składa się z czterech części. We wstępie zawarte zostały rozstrzygnięcia terminologiczne oraz umiejscowienie antropologicznych rozważań Mariana Przełęckiego, zarówno na tle filozoficznej szkoły, w duchu której prowadził swoją naukową działalność, jak i ich lokalizacji w jego twórczo-

M. Przełęcki, Moja filozofia, w: A. Brożek, J. Jadacki (red.), Księga pamiątkowa Marianowi Przełęckiemu $w$ darze na 90-lecie urodzin, Norbertinym, Lublin 2014, s. 7. 
ści. Część druga koncentruje się wokół zagadnienia ludzkiej dobroci i zawiera w sobie także omówienia poglądów innych myślicieli, z którymi Marian Przełęcki się zgadzał lub wchodził w polemikę. Część trzecia analizuje jego stosunek do Pascalowskiej wizji człowieka, część czwarta zaś prezentuje poglądy filozofa na kwestie determinizmu oraz relacji ludzi do zwierząt.

Antropologia - nauka koncentrująca się na człowieku - może być uprawiana $\mathrm{w}$ ramach różnych dyscyplin. W odniesieniu do myśli Mariana Przełęckiego należy ją rozumieć ściślej, w znaczeniu, w jakim niekiedy mówi się o wąsko rozumianej filozofii człowieka. Jest do dział filozofii starający się znaleźć odpowiedź na pytanie: czym jest człowiek? Próbuje uchwycić naturę człowieka, istotę jego osobowego bytu. Biorąc pod uwagę ludzką działalność, stara się wyjaśnić, jakie miejsce zajmuje człowiek w świecie przyrody oraz w społeczeństwie. Zagadnienia antropologiczne raczej nie były podejmowane wprost przez filozofów związanych ze Szkołą Lwowsko-Warszawską ${ }^{2}$, choć można oczywiście doszukiwać się takich wątków pobocznie, np. przy okazji pewnych przemyśleń etycznych. Nakreślony przez Tadeusza Kotarbińskiego ideał spolegliwego opiekuna, $\mathrm{z}$ całym szeregiem charakteryzujących go cech, bez wątpienia zawiera w sobie pewną koncepcję człowieka. Niemniej jednak hasło „antropologia” na gruncie XX-wiecznej filozofii polskiej przywodzi na myśl nazwiska reprezentantów zupełnie innych nurtów filozoficznego dyskursu³. Zainteresowania tematyką antropologiczną można natomiast dostrzec wśród uczniów, którzy kształcili się pod kierunkiem czołowych przedstawicieli Szkoły Lwowsko-Warszawskiej i współpracowali z nimi w okresie powojennym. Najbardziej zagadnienie to pochłonęło Andrzeja Grzegorczyka ${ }^{4}$. Wyrazem jego antropologicznych zaintere-

\footnotetext{
Chodzi tu o samego Kazimierza Twardowskiego oraz jego bezpośrednich uczniów.

Wskazać tu można fenomenologa Romana Ingardena i jego Książeczkę o człowieku (R. Ingarden, Książeczka o człowieku, Wydawnictwo Literackie, Kraków 1998), personalistyczne rozważania Karola Wojtyły zawarte w tomie Osoba i czyn K. Wojtyła, (Osoba i czyn oraz inne studia antropologiczne, Towarzystwo Naukowe Katolickiego Uniwersytetu Lubelskiego, Lublin 2000), czy też refleksje w obrębie filozofii dialogu prowadzone przez Józefa Tischnera (J. Tischner, Spór o istnienie człowieka, Wydawnictwo Znak, Kraków 2011).

4 W latach 1946-1948 pełnił on funkcję asystenta Władysława Tatarkiewicza.
} 
sowań są książki takie jak Schematy i człowiek ${ }^{5}$, czy też Psychiczna osobliwość człowieka $a^{6}$. U Mariana Przełęckiego takich zwartych publikacji dotyczących filozofii człowieka szukać próżno. Jedyną kwestią antropologiczną, którą poruszał wprost, było pytanie, czy ludzie są dobrzy. Pozostałe splatają się z rozważaniami etycznymi lub dotyczącymi przekonań religijnych. Powodów, dla których Przełęcki dotykał filozofii człowieka, można wskazać kilka. Z całą pewnością, podobnie jak w wypadku rozważań dotyczących przekonań religijnych i sensu ludzkiego życia, ogromną rolę odegrały tu inspiracje czerpane $\mathrm{z}$ wypowiedzi innych myślicieli, bliskich filozofowi prywatnie lub z którymi jego ścieżki połączyła praca zawodowa. Wymienić tu należy wspomnianego wyżej Andrzeja Grzegorczyka, ale także Leszka Kołakowskiego i Bogusława Wolniewicza, z którym Przełęcki przez pięć lat prowadził seminarium zatytułowane „Logika i filozofia”7. Kwestie antropologiczne implikowała także skonstruowana przez filozofa koncepcja etyczna chrześcijaństwa niewierzących. Ponieważ był agnostykiem, nie mógł odwołać się przecież do chrześcijańskiej wizji człowieka, według której człowiek został celowo powołany do istnienia na obraz i podobieństwo Boga. Pewne założenia antropologiczne zostały także przez filozofa przywołane i wplecione w rozważania o racjonalności.

\section{Dyskusja o ludzkiej dobroci}

Pytanie o to, czy człowiek jest z natury dobry czy też zły, jest zagadnieniem starym i wielokrotnie podejmowanym w obrębie dyskursu filozoficznego. Odpowiedzi na nie podjął się także Marian Przełęcki, zainspirowany przemyśleniami Leszka Kołakowskiego, który w 2009 roku opublikował esej Ludzie sq dobrzy ${ }^{8}$. A ponieważ filozof $\mathrm{z}$ większością zawartych $\mathrm{w}$ tym tekście refleksji się zgadzał, zasadne wydaje się w tym miejscu krótkie jego streszczenie. Kołakowski wyszedł w nim od następującego stwierdzenia:

A. Grzegorczyk, Schematy i człowiek, Społeczny Instytut Wydawniczy „Znak”, Warszawa 1963.

A. Grzegorczyk, Psychiczna osobliwość człowieka, Wydawnictwo Naukowe Scholar, Warszawa 2003.

7 W roku akademickim 1973/74, wówczas w zajęciach uczestniczył m.in. Roman Suszko, a następnie od roku 1977 do roku 1981.

8 L. Kołakowski, Ludzie sq dobrzy, w: L. Kołakowski, Czy Pan Bóg jest szczęśliwy i inne pytania, Wydawnictwo Znak, Kraków 2009, s. 240-247. 
Jest w nas korzeń zła i nie mamy siły, by go z naszego bytu do szczętu wyrwać, ale jest też nasienie dobra, które użyźniać możemy. Jest to pewien obraz świata zdroworozsądkowy i banalny, któremu większość z nas przytaknie: jesteśmy źli czasem, a czasem dobrzy, nosimy w sobie obie jakości: dobro i zło, ale - i to jest trywialna prawda - w różnych proporcjach u różnych ludzi. Ile jednego, i ile drugiego, tego wyliczyć niepodobna, ale reagujemy żywiołowo na ludzkie uczynki i charaktery stosownie do naszych całkiem nie matematycznych kalkulacji ${ }^{9}$.

Następnie zwrócił uwagę, że w historii filozofii, od Sokratesa przez Thomasa Hobbesa i we wczesnych przemyśleniach Davida Hume'a, po poglądy utylitarystów, funkcjonuje przekonanie, że ludzie w swym działaniu kierują się przede wszystkim interesem własnym. Zdaniem filozofa założenie to ma formę psychologicznego opisu i trudno je podważyć, odwołując się do empirii, bo nawet w działaniach ludzi uważanych za świętych można doszukiwać się pierwiastka motywacji egoistycznej, wyrażającej się oczekiwaniem nagrody w niebie. Z drugiej strony odniesienie do stanów wewnętrznych stanowi jednocześnie znaczącą słabość tego twierdzenia, bo jeśli uważamy, że nasze motywacje są bezinteresowne, w wielu wypadkach nie sposób bezspornie udowodnić, że tak nie jest. Kolejną myślą, w której Kołakowski szukał rozwikłania zagadki dobra i zła w ludzkiej naturze, jest antropologia chrześcijańska, wedle której człowiek jako jedno z dzieł Bożych jest dobry, co postrzegać należy jako założenie metafizyczne. Zło pojawia się w tej koncepcji jako pokłosie wyborów wolnej woli, jaką zostali obdarzeni ludzie. Swoboda decyzji, możliwość postąpienia dobrze lub źle otwiera moralny wymiar ludzkiej egzystencji, w którym o odpowiedź na pytanie, czy człowiek jest dobry, o wiele trudniej. Kołakowski, usilnie poszukując pozytywnego rozstrzygnięcia tej kwestii, odwołał się do zasady wyznawanej przez kwakrów ${ }^{10}$, która głosi, że w każdym człowieku jest pierwiastek dobra, nazywany przez nich także Bożą iskrą. Odrywając to przekonanie od kontekstu religijnego, można sparafrazować je w tezie, że każdy człowiek nosi w sobie potencjalną zdolność do czynienia dobra, predyspozycje do bezinteresownej miłości bliźniego. Niestety idea ta, podobnie jak założenie o egoistycznych pobudkach wszelkich działań ludzkich, jest nieweryfikowalna. Kołakowski uważał, że ze względu na to, wia-

\footnotetext{
9 Tamże, s. 240.

10 Kwakrzy - potoczna nazwa Religijnego Towarzystwa Przyjaciół, wspólnoty chrześcijańskiej wywodzącej się z purytanizmu.
} 
ra w tkwiącą w człowieku zdolność do czynienia dobra bardziej przekonująco wypada skorelowana $z$ konkretnymi wierzeniami, a jej wartość ujawnia się, gdy spojrzymy na nią z perspektywy praktycznych skutków, jakie za sobą niesie. Pisał on:

Jeśli wierzymy w tę prawdę, wierzymy zarazem, że nikt nie jest absolutnie i bezwzględnie skorumpowany i do niczego prócz zła niezdolny (...). Tym samym trzeba nam zakładać, że środki wychowawcze stosowane, by ludzi uczynić lepszymi, mają zawsze szansę powodzenia ${ }^{11}$.

Wiara $\mathrm{w}$ tkwiący $\mathrm{w}$ człowieku pierwiastek dobra czyni sensownymi działania wychowawcze, pozytywne środki stosowane, aby zmagać się ze złem. Stanowi też asumpt ku temu by przypuszczać, że w niektórych przypadkach w uwarunkowaniach społecznych jednostki doszukiwać się należy przyczyn jej niegodziwego postępowania. Kołakowski podkreślał jednak, że jego przemyślenia są wyłącznie pewną propozycją podejścia do problemu dobra i zła w człowieku oraz nie chciał, by były one traktowane jako konkretna teoria natury ludzkiej.

Marian Przełęcki zgadzał się w większości z przemyśleniami Leszka Kołakowskiego, uznał jednak, że propozycja ta domaga się pewnych uzupełnień i komentarzy, zarówno w zakresie treści, jak i jej metodologicznego statusu. Jego uwagę przykuło zwłaszcza pojęcie dobra moralnego. Kołakowski zdawał się interpretować je jako bezinteresowną miłość bliźniego, co budziło aprobatę Przełęckiego, który za czyny moralnie właściwe uznawał działania altruistyczne, mające swoje źródło w trosce o dobro drugiego człowieka. Jednocześnie Przełęcki zauważał, że owo dobro bliźniego może być rozumiane na dwa sposoby: jako przymnożenie radości lub ochrona przed cierpieniem i podążając za postulowaną przez realizm praktyczny Tadeusza Kotarbińskiemu hierarchią wartości, większą doniosłość dostrzegał w zapobieganiu złu. Zwrócił uwagę, że w propozycji Kołakowskiego kluczową rolę odgrywa motywacja, której istota jego zdaniem tkwi w zdolnościach człowieka do empatii, a ściślej mówiąc umiejętności współczucia. Sądził, że skłonność do pomagania bliźnim bierze się z dyskomfortu, jaki odczuwamy obcując z cierpieniem drugiego człowieka. Był świadom, że taki rodzaj motywacji stawia pod znakiem zapytania altruizm danego czynu. Pisał:

$\overline{11}$ L. Kołakowski, Ludzie sq dobrzy..., dz. cyt. s. 245. 
Czy nie postępuję raczej samolubnie, jeśli z dwóch stojących przede mną możliwości wybieram po prostu tę, która sprawia mniej przykrości? Pomoc cierpiącemu raczej niż trudny do zniesienia ból współczucia? Myślę, że altruistyczny charakter takiej motywacji można widzieć właśnie w tym, że cierpienie, którego chcę uniknąć, jest moją reakcją na cierpienie innego człowieka. Altruistyczny niewątpliwie jest też zamierzony cel mojego czynu: pomoc innej istocie ludzkiej ${ }^{12}$.

Kołakowski tezę, że w każdym człowieku tkwi zdolność do czynu moralnie dobrego, uważał za tezę nierozstrzygalną, pozbawioną empirycznego sensu. Przełęcki przeciwnie, podjął się próby przypisania jej takiego właśnie sensu, chociaż zdawał sobie sprawę, że sformułowana za pomocą kwantyfikatora „każdy” nie daje perspektyw na jednoznaczną weryfikacje bądź falsyfikację w oparciu o empiryczne przesłanki. Widział jednak możliwości uzasadnia jej częściowo. Sądził, że o ile rzeczywiście odwołanie się do motywacji, a więc do pewnych stanów psychicznych stanowi pewną trudność, to jednak można ich w pewnym stopniu dowodzić, chociażby poprzez wnioskowanie o cudzych przeżyciach na drodze analogii do doświadczeń własnych. Dla Przełęckiego większym kłopotem w tezie postawionej przez Kołakowskiego był fakt, że mówi ona o pewnej dyspozycji do czynienia dobra, nie zaś o konkretnych zdarzeniach. A w związku z tym, jeśli odrzuci się dodatkowe przesłanki natury religijnej, jedynym sposobem jej weryfikacji okazuje się zaistnienie potwierdzającego ją czynu moralnie dobrego. Mówiąc prościej, aby jednoznacznie określić, czy w danym człowieku tkwi potencjał do dobrego działania, musi on przynajmniej raz postąpić moralnie właściwie. Ostatecznie filozof zmuszony był zgodzić się z Kołakowskim, że jest to wyłącznie hipoteza, której przyjęcie stanowi bardziej akt wiary niż wiedzy, ale którą akceptował, intuicyjnie ${ }^{13}$ uznając, że bardziej prawdopodobnym wydaje się to, że każdy człowiek posiada zdolność do czynienia dobra, niż to, że takiej predyspozycji nie posiada. Przełęcki, idąc w ślad za Kołakowskim przyznawał, że dużo bardziej przekonujące są w tej kwestii przesłanki natury pozapoznawczej, mające swoje odzwierciedlenie w stosunku do drugiego człowieka. Wyraźnie dostrzegał

12 M. Przełęcki, Czy ludzie sq dobrzy?, w: „Edukacja Filozoficzna” 2009, nr 49; przedruk w: A. Brożek, J. Jadacki, M. Przełęcki, $W$ poszukiwaniu najwyższych wartości. Rozmowy międzypokoleniowe, Wydawnictwo Naukowe Semper, Warszawa 2011, s. 87.

13 Zob. M. Przełęcki, Sens i prawda w etyce, Znak-Język-Rzeczywistość, Polskie Towarzystwo Semiotyczne, Warszawa 2004, s. 31-32. 
korelacje między przyjmowaniem tezy, że w każdym człowieku tkwi zdolność do czynienia dobra, a postępowaniem względem innych, wiarą, że zło można pokonać dobrem. Zauważył, że ową „kwakierską” moralną normę przyjmował w swoim życiu Tadeusz Kotarbiński. Jednocześnie dostrzegał, że oprócz aprobaty owej tezy, można spotkać się z jej stanowczą krytyką, której wyrazicielem stał się Bogusław Wolniewicz, poprzez zbudowanie pewnej teorii antropologicznej.

Warto w tym momencie wspomnieć, co zainspirowało Wolniewicza do skonstruowania takiej właśnie koncepcji i pokrótce zarysować jego propozycję. Przyczynkiem do niej była bowiem zawarta w tekście Mariana Przełęckiego $O$ dwóch koncepcjach postępowania moralnego ${ }^{14}$ polemika z poglądami filozofa dotyczącymi motywacji etycznej. Bogusław Wolniewicz był zdania, że dyskusja ta ujawniła dwa odmienne spojrzenia na naturę ludzką. Pierwsze z nich, przypisywane Przełęckiemu, określił jako melioryzm, drugie, z którym się utożsamiał, jako pejoryzm. Pisał:

Przez melioryzm rozumiem przeświadczenie, że nikt świadomie nie dąży do złego, wszyscy dążą stale in meliora, „ku lepszemu”. Pejoryzm jest negacją melioryzmu: nie wszyscy tak dążą, bo niektórzy dążą świadomie in peiora, $k u$ gorszemu"15.

Zdaniem Wolniewicza dla pejorystów podstawą sumienia jest wrodzony i niezmienny charakter. Potwierdzeniem owej stałości ludzkiej natury mają być dokonania współczesnej nauki, które donoszą, że wszystkie nasze cechy zdeterminowane są w genetycznym zapisie. Melioryści natomiast po Kantowsku utożsamiają sumienie $\mathrm{z}$ rozumem praktycznym $\mathrm{i}$ wierzą $\mathrm{w}$ to, że każdy jest zdolny do czynu dobrego. W kwestii charakteru opowiadają się za jego plastycznością, a przyczyn wszelkiej słabości skłonni są upatrywać w niekorzystnych uwarunkowaniach społecznych i złych doświadczeniach jednostki. W recepcji Przełęckiego rozważania Wolniewicza sprowadzają się do tezy, że istnieją ludzie pozbawieni zdolności do czynienia dobra, bezwzględnie źli. Wydawała się ona filozofowi nieprzekonująca i gotów był ją raczej postrzegać w kategorii pesymistycznego uogólnienia szeregu pewnych empirycznych doświadczeń. Wyrażał przekonanie, że równie dobrze można wskazać wiele budujących przykładów przemian ludzkich

14 M. Przełęcki, O dwóch koncepcjach postępowania moralnego, „Edukacja Filozoficzna” 2007, nr 44, s. 19-26.

15 B. Wolniewicz, Melioryzm contra pejoryzm, w: B. Wolniewicz, Filozofia i wartości, t. 4, Wydawnictwo Uniwersytetu Warszawskiego, Warszawa 2016, s. 273. 
charakterów. Bogusław Wolniewicz, prowadząc swoje rozważania, posłużył się dość drastycznym przykładem zła, przytaczając historię dwóch młodzieńców znęcających się nad kotami ${ }^{16}$. Zdaniem Mariana Przełęckiego opowieść ta ilustrowała nie tyle zachowanie moralnie złe, co sadystyczne, w którym podmiotowi działającemu sprawia przyjemność cudze cierpienie. Dla pejorysty takie zachowanie, będące wyrazem braku empatii, stanowi przejaw złego charakteru. Meliorysta gotów jest postrzegać je w kategoriach patologii, za którą zwykle kryją się jakieś traumy. Przełęcki sądził, że takie dysfunkcje bywają naprawialne. Ponadto zauważał, że często osoba o skłonnościach sadystycznych nie przejawia tego typu zachowań wobec wszystkich i równolegle potrafi być opiekuńcza np. wobec swoich bliskich, czyli zdolność do czynienia dobra nie tylko posiada, ale i realizuje ${ }^{17}$. Wolniewicz ripostował, że to forma usprawiedliwiania człowieka, która odpowiedzialność za zło przerzuca na czynniki zewnętrzne. Punktował, że nie każdy złoczyńca ma za sobą złe doświadczenia i, odwrotnie, nie każdy, kto przeszedł przez pewne traumatyczne perypetie, postępuje moralnie niewłaściwie. Tłumaczy, że:

Pejorysta nie twierdzi, że „są ludzie niezdolni do żadnego czynu dobrego”, bo coś dobrego może zrobić nawet diabeł. Twierdzi jedynie, że ludzie bywają zdolni do czynów diabelskich; i że to widać ${ }^{18}$.

Ponadto zdaniem Wolniewicza meliorysta uciekając się do pojęcia patologii, medykalizuje zło, jednocześnie popełniając w swoim rozumowaniu błąd petitio principii. Jeśli bowiem postępowanie moralnie naganne uważa za odchylenie, to podświadomie zakłada, że człowiek jest z natury dobrotliwy, czyli tezę, którą próbuje bronić.

Konflikt między zdeklarowanym pejorystą, a zdecydowanym meliorystą wydaje się nierozstrzygalny, pojawia się jednak pytanie, które stanowisko przemówiłoby do osoby próbującej się dopiero w tej kwestii określić. Oba punkty widzenia mają swoje mankamenty. Pejoryzm, bardzo klarownie wyłożony przez Bogusława Wolniewicza, razi zbyt dużą wiarą w genetyczne zdeterminowanie. Można mu również zarzucić, że w pewien sposób medykalizuje zło, traktując je jako nieuleczalną chorobę złego charakteru. Prowokuje, by poprosić o definicję

\footnotetext{
Zob. B. Wolniewicz, Melioryzm..., dz. cyt., s. 275.

Zob. M. Przełęcki, Czy ludzie..., dz. cyt., s. 90-91.

B. Wolniewicz, W sprawie pejoryzmu, w: B. Wolniewicz, Filozofia..., dz. cyt., s. 291.
} 
złego i dobrego charakteru oraz wyznaczenie między nimi wyraźnej linii demarkacyjnej. Przyglądając się otaczającej rzeczywistości, możemy zaobserwować, że ludzie zachowują się różnie w zależności od całego szeregu czynników, zarówno tych wewnętrznych, czyli samopoczucia, systemu przekonań, itd., jak i zewnętrznych okoliczności, np. inaczej reagują $\mathrm{w}$ relacjach $\mathrm{z}$ osobami bliskimi, albo też $\mathrm{w}$ sprawach dla danego człowieka ważnych. Pojawia się zatem pytanie, w jaki sposób wyciągnąć pewną charakterologiczną średnią? Na płaszczyźnie praktyki pejoryzm zdaje się zachęcać do bierności, przekreśla sens działań wychowawczych, ale także pracy nad samym sobą. I z tego względu właśnie, melioryzm wydaje się dużo lepszą alternatywą. Opcją, która daje nadzieję, że może być lepiej i inspiruje do działania, by próbować dokonywać zmian ku poprawie. Jest przy tym propozycją wymagającą umiejętności obiektywnego spojrzenia na zaistniałą sytuację, a także realnego oszacowania możliwości własnych i drugiego człowieka. Może okazać się, więc niebezpieczny w sytuacjach nadmiernego emocjonalnego zaangażowania. Przykładowo zakochana w oprawcy ofiara przemocy, będzie nieustannie go usprawiedliwiać i wierzyć w poprawę sytuacji, narażając przy tym swoje zdrowie i życie. Dobrym połączeniem wydaje się w tym kontekście przyjęcie założenia melioryzmu i działanie według dyrektyw realizmu praktycznego.

Wracając do antropologicznych rozważań Mariana Przełęckiego, zauważył on, że Kołakowski wskazał na jedną możliwość zaprzeczenia tezie, że każdy człowiek jest zdolny do moralnie dobrego działania. Wiąże się ona $\mathrm{z}$ wszelkiego rodzaju stanowiskami hedonistycznymi czy utylitarystycznymi, które głoszą, że człowiek, działając, zawsze kieruje się własną korzyścią. Założenie to przekreśla możliwość czynów podyktowanych troską o dobro drugiego człowieka, czyli właśnie interpretowanych przez obu filozofów jako moralnie dobrych. Kołakowski próbował zniwelować zagrożenie płynące ze strony tych, przypisujących wszelkiemu ludzkiemu postępowaniu motywy egoistyczne, teorii, uznając je za empirycznie nierozstrzygalne. Przełęcki sprowadził tę teorię do dwóch tez. Pierwsza zwana „psychologicznym hedonizmem”, mówi o tym, że:

każdy człowiek dąży zawsze do tego, do czego mu jest przyjemniej (lub mniej przykro) dążyćc ${ }^{19}$.

19 M. Przełęcki, Czy ludzie..., dz. cyt., s. 91. 
W jego opinii wydaje się ona znajdować potwierdzenie w potocznym doświadczeniu. Stanowiska, które akcentują egoistyczne motywacje człowieka, opierają się jednak na dużo mocniejszym stwierdzeniu, głoszącym, że:

Każdemu człowiekowi zawsze jest przyjemnie (lub mniej przykro) dążyć do dobra własnego niż do dobra cudzego ${ }^{20}$.

Zdaniem Mariana Przełęckiego tezie tej przeczą czyny motywowane empatią. Osoba głęboko współodczuwająca cierpienia innych ludzi, gotowa jest poświęcić swój komfort i pomóc drugiemu człowiekowi. Mniej przykre są dla niej trud własny i pewne wyrzeczenia, niż dojmujące uczucie litości, którego doświadcza obcując z nieszczęściem bliźniego. Stąd za zasadne uznaje postulaty hedonizmu odrzucić.

Stanowisko Mariana Przełęckiego w kwestii ludzkiej dobroci stało się punktem wyjścia do dalszej debaty, którą podjęli Anna Brożek oraz Jacek Jadacki na łamach książki $W$ poszukiwaniu najwyższych wartości. Rozmowy międzypokoleniowe ${ }^{21}$.

\section{Pascalowska koncepcja człowieka w recepcji Mariana Przełęckiego}

W artykule Prawo do wiary ${ }^{22}$ Marian Przełęcki wprost przyznaje, że źródłem jego poczuć moralnych jest konkretna wizja człowieka. Pesymistyczny obraz ludzkiej egzystencji, który odnalazł na kartach Myśli Blaise’a Pascala, a zwłaszcza we fragmencie mówiącym o obserwowaniu śmierci cudzej i oczekiwaniu na własnąą Nawiązanie to wydaje się zaskakujące o tyle, o ile w rozważaniach o sprawach ostatecznych Przełęcki deklarował się jako zwolennik stanowiska epikurejskie-

\footnotetext{
Tamże, s. 92.

A. Brożek, J. Jadacki, M. Przełęcki, W poszukiwaniu najwyższych wartości..., dz. cyt.

M. Przełęcki, Prawo do wiary, w: M. Przełęcki, O rozumności i dobroci, Wydawnictwo Naukowe Semper, Warszawa 2002, s. 98-104.

23 „Wyobraźmy sobie gromadę ludzi w łańcuchach, skazanych na śmierć, codziennie kat morduje jednych na oczach drugich, przy czym ci, którzy zostają, widzą własną dolę w doli swoich bliźnich i, spoglądając po sobie z boleścią a bez nadziei, czekają swojej godziny. Oto obraz doli ludzkiej” - B. Pascal, Myśli, Instytut Wydawniczy Pax, Warszawa 2012, s. 136.
} 
go $^{24}$, w którym nie ma racjonalnych przesłanek ku temu, by obawiać się kresu własnej egzystencji. Filozof pisał:

Jak nikt inny, widzi Pascal - obok wielkości - nędzę człowieka: tego „robaka ziemi”, zawieszonego „między dwiema otchłaniami Nieskończonością i Nicością". Przejmująco trafna wydaje mi się ta wizja człowieka i jego losu. Przemawiają za nią moje najgłębsze doświadczenia egzystencjalne, w których człowiek (każdy człowiek!) jawi mi się jako ktoś, kto budzi najwyższe współczucie, kto zasługuje na nieograniczone miłosierdzie ${ }^{25}$.

Pascalowa antropologia zdaje się przemawiać do Przełęckiego w kontekście relacji człowiek - świat. Z tej perspektywy istota ludzka jawi się jako krucha oraz przytłoczona świadomością własnej przemijalności. Można się w tym miejscu pokusić o spekulacje, skąd u filozofa żyjącego w czasach naznaczonych technologicznym postępem, wiarą w tkwiący w człowieku potencjał do okiełznania nie tylko sił przyrody, ale także własnej fizycznej słabości (wynikającą z ogromnego rozwoju medycyny), tak przejmujące doświadczenia egzystencjalne. Nasuwają się tutaj dwie hipotetyczne przyczyny. Pierwsza z nich dotyczy rzeczy samej w sobie pozytywnej, a mianowicie ogromnej wrażliwości filozofa na piękno przyrody. Marian Przełęcki wraz z żoną Aleksandrą mieli w zwyczaju spędzać wakacje $\mathrm{w}$ górach ${ }^{26}$. Obcowanie z majestatem tatrzańskich szczytów napawa zachwytem, ale też uświadamia małość człowieka względem potęgi przyrody. Wędrówki górskie, nawet te po względnie bezpiecznych i oznakowanych szklakach, uczą człowieka pokory wobec wytworów natury, ale także własnych możliwości. Drugi hipotetyczny powód antropologicznego pesymizmu filozofa stanowi biograficzne doświadczenie dramatu militarnego konfliktu. Wojenna pożoga dotknęła Mariana Przełęckiego w młodzieńczym okresie jego życia, czyli czasie kształtowania się jego osobowości i poglądów na świat.

W antropologicznej wizji Blaise’a Pascala, oprócz czynników świadczących o ludzkiej słabości, można odnaleźć także elementy, które przemawiają na rzecz

24 Zob. M. Przełęcki, Czas i życie wieczne, w: A. Brożek, J. Jadacki, M. Przełęcki, W poszukiwaniu najwyższych wartości..., dz. cyt., s. 286.

25 M. Przełęcki, Prawo do..., dz. cyt., s. 100.

26 Zob. Wywiad z prof. Marianem Przełęckim z cyklu „Wywiady z nestorami filozofii polskiej”, http://academicon.pl/2016/03/29/wywiad-z-prof-marianem-przeleckim-z-cyklu-wywiady-z-nestorami-filozofii-polskiej-odc-3/. 
wielkości i pozytywnie rozumianej wyjątkowości człowieka ${ }^{27}$. Najważniejszym z nich jawi się rozumność. Francuski filozof pisał:

Człowiek jest tylko trzciną, najwątlejszą w przyrodzie, ale trzciną myślącą. Nie potrzeba, by cały wszechświat uzbroił się, aby go zmiażdżyć: mgła, kropla wody wystarczą, aby go zabić. Ale gdyby nawet wszechświat go zmiażdżył, człowiek byłby i tak czymś szlachetniejszym niż to, co go zabija, ponieważ wie, że umiera, i zna przewagę, którą wszechświat ma nad nim. Wszechświat nie wie nic o tym. Cała nasza godność spoczywa tedy w myśli. Z niej trzeba nam się wywodzić, a nie z przestrzeni i czasu, których nie umielibyśmy zapełnić. Silmy się tedy dobrze myśleć: oto zasada moralna ${ }^{28}$.

Podobnie godność ludzką rozumiał Marian Przełęcki, co ujawnił broniąc racjonalnego poglądu na świat ${ }^{29}$. W początkowym okresie swojej działalności naukowej, analogicznie do Pascala, skłonny był uważać jasność myśli za moralną powinność. Z czasem złagodził swoje zapatrywania w tej kwestii i chociaż nadal wysoko cenił intelektualny honor, naczelne miejsce $\mathrm{w}$ hierarchii wartości filozofa zajęło miłosierdzie, ufundowane na współczuciu wobec cierpienia bliźniego. Nakreślony przez Pascala obraz ludzkiej natury jest dynamiczny, naznaczony ciągłym poczuciem niedosytu, pogonią za szeroko rozumianym szczęściem, inspirującą poszczególne jednostki do działania ${ }^{30}$. Człowieka wyłaniającego się z rozważań Mariana Przełęckiego również charakteryzuje aktywność i dążenie do szczęścia ${ }^{31}$. W tym jednak aspekcie ujawnia się znacząca różnica między koncepcjami antropologicznymi obu filozofów. Stanowisko Pascala ma swoje mocne zakorzenienie w wierze chrześcijańskiej, stąd wszelka ludzka działalność nabiera sensu dopiero, gdy za cel obiera sobie spotkanie z Bogiem w niebie. Przełęcki metafizyczne złożenia odrzucał, ale wierzył w wieczność prawdy o dobrych uczyn-

27 Adam Węgrzecki, analizując koncepcje człowieka Pascala, wyróżnia sześć takich elementów 1. Złożoność ludzkiej natury z ciała i ducha 2. Rozumność. 3. Zdolność do kochania 4. Odczucie ciągłego niedosytu powodujące ruch ludzkiej natury 5. Dynamizm 6. Pragnienie szczęścia; Zob. A. Węgrzecki, Koncepcja człowieka u Blaise Pascala, w: Z. Żarnecka (red), Szkice Filozoficzne: Romanowi Ingardenowi w darze, Państwowe Wydawnictwo Naukowe, Warszawa 1964, s. 371373.

B. Pascal, Myśli, dz. cyt., s. 107-108.

29 Zob. M. Przełęcki, O metafizyce teistycznej, w: M. Przełęcki, Horyzonty metafizyki, Wydawnictwo Naukowe Semper, Warszawa 2007, s. 80-81.

30 Zob. A. Węgrzecki, Koncepcja człowieka u Blaise Pascala, s. 373.

31 Zob. M. Przełęcki, W sprawie realizmu praktycznego, w: M. Przełęcki, Horyzonty..., dz. cyt., s. 37. 
$\mathrm{kach}^{32}$. Dlatego moralnie właściwa aktywność może być w świetle jego koncepcji rozumiana jako jedyna szansa śmiertelnego człowieka na pozostawienie po sobie niezatartego śladu własnego istnienia.

\section{Poglądy na kwestię determinizmu oraz relacji ludzi do zwierząt}

Większość myślicieli Szkoły Lwowsko-Warszawskiej skłaniała się ku tezie o zdeterminowaniu ludzkiej woli. Pogląd taki wyrażał zarówno sam założyciel Szkoły Kazimierz Twardowski ${ }^{33}$, jak i jego uczniowie, m.in. Tadeusz Kotarbiński, który pisał, że:

Naszym zdaniem, podleganie we wszystkim, co się robi, powszechnym prawom zdarzeń nie wyklucza aktów wyboru, które mogą odbywać się wedle tych praw, gdyż wybór takich, a nie innych czynów nie dotyczy respektowania owych praw stawania się lub wyłamywania się z nich, lecz dotyczy decyzji pójścia $\mathrm{w}$ prawo lub lewo, $\mathrm{w}$ każdym przypadku zgodnie $\mathrm{z}$ prawami ruchu i prawami motywacji ${ }^{34}$.

W tym samym duchu za determinizmem opowiadał się Marian Przełęcki ${ }^{35}$. Wątek ten pojawił się m.in. w kontekście polemiki na temat twórczości opartej na tezie wyrażonej w rozprawie Psychiczna osobliwość człowieka. Jej autor, Andrzej Grzegorczyk, analizując wyjątkowość istoty ludzkiej na tle innych gatunków, wskazał, że czynnikiem najbardziej wyróżniającym człowieka jest twórczość. Marian Przełęcki ogólnie akceptował argumentację prowadzącą do tej konkluzji, jednak nie zgadzał się z jedną zawartą w niej kwestią. Grzegorczyk twierdził, że twórczość ludzka nierozerwalnie łączy się z wolnością woli, postulując tym samym niezdeterminowanie niektórych ludzkich zachowań. Przełęcki natomiast był zdania, że nie ma podstaw ku temu, by w tym kontekście odrzucać zasadę powszechnego determinizmu ${ }^{36}$. Sądził, że twórczość jest możliwa także

32 Zob. M. Przełęcki, Uwagi o sensie życia i śmierci, w: M. Przełęcki, Horyzonty..., dz. cyt., s. 44.

33 Zob. np. K. Twardowski, Etyka i prawo karne wobec zagadnienia wolności woli, „Etyka” 1983, nr 20, s. 123-159.

34 T. Kotarbiński, Hasło życia zgodnego z natura, w: T. Kotarbiński, Pisma etyczne, Zakład Narodowy im. Ossolińskich, Wrocław 1987, s. 370.

35 Zob. np. M. Przełęcki, Przekonania jako przedmiot oceny moralnej, w: M. Przełęcki, O rozumności i dobroci, Wydawnictwo Naukowe Semper, Warszawa 2002, s. 79-87.

36 Zob. M. Przełęcki, Człowiek a zwierzę, w: M. Przełęcki, Intuicje moralne, Wydawnictwo Nauko- 
bez zakładania indeterminizmu. W rozprawie Psychiczna osobliwość człowie$k a$ empirycznie rozróżnia się zachowania szablonowe, które są odruchowe lub wymagają jedynie przypomnienia sobie schematu działania, oraz zachowania twórcze przełamujące rutynę. Wybór zachowania twórczego opiera się na dwóch elementach - dostrzeżeniu nowej możliwości oraz oszacowaniu jej zastosowania jako cenne. Andrzej Grzegorczyk nazywał sytuacje takich wyborów jako momenty twórczości i traktował jako chwile, w których „realizuje się metafizyczna wolność jednostki ludzkiej"37. Marian Przełęcki interpretował je w sposób odmienny. Uważał, że decyzje takie nie są wolne od zdeterminowania przyczynowego. Podjęcie ich warunkuje okoliczność zaistnienia nowej możliwości oraz dokonane przez podmiot działający wartościowanie, które z kolei stanowi wypadkową osobowości oraz bagażu doświadczeń danej jednostki. Filozof dostrzegał w rozumowaniu swego kolegi tezę ostrożniejszą, mówiącą o wolności decyzji, ale w kontekście nie braku jakiegokolwiek zdeterminowania, ale zewnętrznych przyczynowych uwarunkowań. Zakładał, więc w wypadku działań twórczych wyłącznie motywację samoistną. Ale jak twierdzi współczesny psycholog twórczości Edward Nęcka:

Twórczość nie jest bynajmniej wyjątkiem, jeśli chodzi o motywację samoistną, na podobnej zasadzie bowiem przebiega zabawa, swobodna eksploracja lub aktywność seksualna. W takich wypadkach nagrody immanentnie zawarte $\mathrm{w}$ wykonywanych czynnościach powodują, że nie są potrzebne żadne nagrody zewnętrzne ani inne czynniki motywujące ${ }^{38}$.

Opinia ta pozwala wnioskować, że usilnie broniąc metafizycznego założenia indeterminizmu, Andrzej Grzegorczyk nieświadomie działał na rzecz osłabienia swej tezy głównej, akcentującej twórczość jako cechę wyróżniającą gatunek homo sapiens. Bardziej przekonujące wydaje się zatem stanowisko Mariana Przełęckiego, zakładające pewnego rodzaju zdeterminowanie w tej kwestii. Co ciekawe, takie przyczynowe uwarunkowanie można odnaleźć w większości psychologicznych teorii opisujących proces twórczy, zarówno tych klasycznych, jak i współczesnych $^{39}$. Dla przykładu, w koncepcji interakcji twórczej mówi się o procesie ciągłego wzajemnego oddziaływania celu oraz struktur próbnych, zmierzających

we Semper, Warszawa 2005, s. 103-105.

37 A. Grzegorczyk, Psychiczna osobliwość..., dz. cyt., s. 124.

38 E. Nęcka, Psychologia twórczości, Gdańskie Wydawnictwo Psychologiczne, Gdańsk 2005, s. 89.

39

Zob. tamże, s. 35-52. 
do jego realizacji. Kierunek dążenia warunkuje przedsiębrane środki. Wybór celu zawsze jest w pewien sposób zdeterminowany polem możliwości, jakimi dysponuje jednostka, oraz jej preferencjami osobistymi. Rozumiany w ten sposób proces twórczy to nie moment, jak chciał tego Grzegorczyk, ale pewien ciąg przyczyn i skutków. Obrany przez człowieka cel warunkuje jego wartościowanie. Za nowe i cenne będzie postrzegane tylko to, co zgodne $\mathrm{z}$ dążeniami jednostki. Młody artysta plastyk może nosić w sobie cały szereg oryginalnych pomysłów, ale świadomie ograniczać swoją ekspresję, gdy jego celem będzie dostanie się na akademię sztuk pięknych.

Refleksje antropologiczne zmierzają zwykle do tego, by uchwycić wyjątkowość człowieka na tle innych stworzeń. Roman Ingarden pisał:

Natura ludzka polega na nieustannym wysiłku i przekraczaniu granic zwierzęcości tkwiącej w człowieku i wyrastaniu ponad nią, człowieczeństwem i rolą człowieka jako twórcy wartości ${ }^{40}$.

Różnice te akcentował w swoich rozważaniach również Andrzej Grzegorczyk, co skłoniło Mariana Przełęckiego do pewnej refleksji, którą z wahaniem zdecydował się wyrazić.

Wspólność człowieka i zwierzęcia wydaje mi się ważniejsza - metafizycznie i moralnie - od wszelakich dzielących ich różnic. Łączy nas przede wszystkim wspólnota naszej doli. Wszyscy rodzimy się i umieramy; wszystko, co żyje, czeka na śmierć. Łączą nas też przeżycia uczuciowe o najbardziej fundamentalnym charakterze; tak jak my, zwierzęta cierpią i radują się, przeżywają strach, ból i rozkosz, a nawet zdolne bywają - jak wierzy laik - do uczuć takich jak przywiązanie i tęsknota, miłość i uwielbienie dla swego człowieczego opiekuna. Ta wspólnota uczuć, wspólnota naszej doli i niedoli, stwarza w nas poczucie bliskości w stosunku do wszelakich istot zwierzęcych, a zarazem związane z tym poczuciem bliskości, uczucie litości dla tych naszych „braci mniejszych". Wobec faktu ich absolutnej niewinności wszelkie ich cierpienie odczuwamy jako niezasłużoną krzywdę, a cierpienia okrutne lub bezmyślnie zadawane im przez ludzi - jako krzywdę niewybaczalną ${ }^{41}$.

${ }^{40} \quad$ R. Ingarden, Ksiażeczka..., dz. cyt., s. 25.
$41 \quad$ M. Przełęcki, Człowiek..., dz. cyt., s. 106. 
Pogląd ten budzi dwa skojarzenia. Pierwsze odsyła do postaci św. Franciszka z Asyżu, zwłaszcza przez użycie sformułowania „bracia mniejsi”. Założyciel zakonu franciszkanów również, kierując się ogromną wrażliwością na obecne w świecie cierpienie, podkreślał wspólnotę losu ludzi i zwierząt. Żywił takie przekonanie w powiązaniu $\mathrm{z}$ głęboką wiarą w Boga i dobro zawarte w Jego stworzeniu, co oczywiście zupełnie nie współgra z poglądami Mariana Przełęckiego. Zwrócenie uwagi na tę korelacje ma jednak sens z perspektywy głoszonej przez filozofa etyki, koncepcji chrześcijaństwa niewierzących. Odgrywa znaczącą rolę w kreśleniu granic moralnego zobowiązania.

Druga asocjacja po raz kolejny prowadzi do Tadeusza Kotarbińskiego. Nauczyciel Przełęckiego zdawał się uznawać wyższość człowieka nad otaczającą go przyrodą. Ale uprzywilejowanie to nierozerwalnie wiązał z poczuciem odpowiedzialności za otaczający świat. Kwestię zapobiegania cierpieniom zwierząt, traktował w kategoriach moralnego obowiązku spoczywającego na człowieku ${ }^{42}$. Uważał, że chociaż ludzie mają prawo zwierzęta zabijać, powinni dołożyć wszelkich starań oszczędzić im męczarni. Postrzeganie stosunku do zwierząt w kategoriach etycznej powinności wydaje się bliskie spojrzeniu Mariana Przełęckiego.

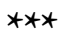

Rozproszone w twórczości Mariana Przełęckiego wątki antropologiczne $\mathrm{z}$ jednej strony ukazują jego wiarę $\mathrm{w}$ tkwiące $\mathrm{w}$ człowieku dobro, a $\mathrm{z}$ drugiej przekonanie o kruchości ludzkiego istnienia. Myśli te stanowią niezbędne tło dla zaproponowanej przez Przełęckiego idei chrześcijaństwa niewierzących. Koncepcji etycznej, w której bardzo istotny element stanowi przeświadczenie, że nie zajmujemy względem drugiego człowieka uprzywilejowanej pozycji. Rozważania antropologiczne pozwalają lepiej zrozumieć, czemu w chrześcijaństwie niewierzących tak mocno akcentowane są wrażliwość na ludzką krzywdę i poczucie międzyludzkiej solidarności. Wyjaśniają, rekomendowane przez Przełęckiego, powstrzymanie się od moralnego osądu drugiego człowieka, który mimo niewłaściwego postępowania, nosi w sobie potencjalną zdolność do czynienia dobra.

Abraham Joshua Heschel w swojej książce Kim jest człowiek? pisał:

42 T. Kotarbiński, Unikanie cierpień, w: T. Kotarbiński, Pisma etyczne, Zakład Narodowy im. Ossolińskich, Wrocław 1987, s. 459. 
Impuls do rozmyślań nad człowieczeństwem człowieka pochodzi z dyrektywy naszego sumienia, jak również z intelektualnej ciekawości. To niepokój skłania nas do rozmyślań, nie zaś zwykłe pragnienie, by coś dodać do sumy informacji na temat przedstawiciela gromady ssaków ${ }^{43}$.

Wydaje się, że w przemyśleniach Mariana Przełęckiego znajdujemy zarówno ten niepokój sumienia, jak i intelektualnego wyzwania, by podejmowane problemy przeanalizować jak najdokładniej i jak najpełniej.

\section{Bibliografia}

Brożek A., Jadacki J., Przełęcki M., W poszukiwaniu najwyższych wartości. Rozmowy międzypokoleniowe, Wydawnictwo Naukowe Semper, Warszawa 2011.

Darowski R., Filozofia człowieka. Zarys problematyki, Wydawnictwo WAM, Kraków 2008.

Grzegorczyk A., Psychiczna osobliwość człowieka, Wydawnictwo Naukowe Scholar, Warszawa 2003.

Grzegorczyk A., Schematy i człowiek, Społeczny Instytut Wydawniczy „Znak”, Warszawa 1963.

Heschel A.J., Kim jest człowiek?, Wydawnictwo Uniwersytetu Łódzkiego, Punctum Pracowania Oświatowo-Wydawnicza, Łódź-Warszawa 2014.

Ingarden R., Książeczka o człowieku, Wydawnictwo Literackie, Kraków 1998.

Kołakowski L., Ludzie sa dobrzy, w: L. Kołakowski, Czy Pan Bóg jest szczęśliwy $i$ inne pytania, Wydawnictwo Znak, Kraków 2009.

Kotarbiński T., Hasło życia zgodnego z natura, w: T. Kotarbiński, Pisma etyczne, Zakład Narodowy im. Ossolińskich, Wrocław 1987.

Kotarbiński T., Unikanie cierpień, w: T. Kotarbiński, Pisma etyczne, Zakład Narodowy im. Ossolińskich, Wrocław 1987.

Nęcka E., Psychologia twórczości, Gdańskie Wydawnictwo Psychologiczne, Gdańsk 2005.

Pascal B., Myśli, Instytut Wydawniczy Pax, Warszawa 2012.

${ }^{43}$ A.J. Heschel, Kim jest człowiek?, Wydawnictwo Uniwersytetu Łódzkiego, Punctum Pracowania Oświatowo-Wydawnicza, Łódź-Warszawa 2014, s. 24. 
Przełęcki M., Czas i życie wieczne, w: A. Brożek, J. Jadacki, M. Przełęcki, W poszukiwaniu najwyższych wartości. Rozmowy międzypokoleniowe, Wydawnictwo Naukowe Semper, Warszawa 2011.

Przełęcki M., Człowiek a zwierzę, w: M. Przełęcki, Intuicje moralne, Wydawnictwo Naukowe Semper, Warszawa 2005.

Przełęcki M., Czy ludzie sa dobrzy?, „Edukacja Filozoficzna” 2009, nr 49.

Przełęcki M., Moja filozofia, w: A. Brożek, J. Jadacki (red.), Księga pamiątkowa Marianowi Przełęckiemu $w$ darze na 90-lecie urodzin, Norbertinum, Lublin 2014.

Przełęcki M., O dwóch koncepcjach postępowania moralnego, „Edukacja Filozoficzna" 2007, nr 44.

Przełęcki M., Prawo do wiary, w: M. Przełęcki, O rozumności i dobroci, Wydawnictwo Naukowe Semper, Warszawa 2002.

Przełęcki M., Przekonania jako przedmiot oceny moralnej, w: M. Przełęcki, O rozumności i dobroci, Wydawnictwo Naukowe Semper, Warszawa 2002.

Przełęcki M., Sens i prawda w etyce, Znak-Język-Rzeczywistość, Polskie Towarzystwo Semiotyczne, Warszawa 2004.

Przełęcki M., Uwagi o sensie życia i śmierci, w: M. Przełęcki, Horyzonty metafizy$k i$, Wydawnictwo Naukowe Semper, Warszawa 2007.

Przełęcki M., W sprawie realizmu praktycznego, w: M. Przełęcki, Horyzonty metafizyki, Wydawnictwo Naukowe Semper, Warszawa 2007.

Tischner J., Spór o istnienie człowieka, Wydawnictwo Znak, Kraków 2011.

Węgrzecki A., Koncepcja człowieka u Blaise Pascala, w: Z. Żarnecka (red), Szkice Filozoficzne: Romanowi Ingardenowi $w$ darze, Państwowe Wydawnictwo Naukowe, Warszawa 1964.

Wojtyła K., Osoba i czyn oraz inne studia antropologiczne, Towarzystwo Naukowe Katolickiego Uniwersytetu Lubelskiego, Lublin 2000.

Wolniewicz B., Melioryzm contra pejoryzm, w: B. Wolniewicz, Filozofia i wartości, t. 4, Wydawnictwo Uniwersytetu Warszawskiego, Warszawa 2016.

Wolniewicz B., W sprawie pejoryzmu, w: B. Wolniewicz, Filozofia i wartości, t. 4, Wydawnictwo Uniwersytetu Warszawskiego, Warszawa 2016. 


\section{Źródła multimedialne:}

Wywiad z prof. Marianem Przelęckim z cyklu „Wywiady z nestorami filozofii polskiej”, http://academicon.pl/2016/03/29/wywiad-z-prof-marianem-przeleckim-z-cyklu-wywiady-z-nestorami-filozofii-polskiej-odc-3/.

\section{Streszczenie}

Marian Przełęcki znany jest przede wszystkim ze swojej naukowej twórczości na płaszczyźnie szeroko rozumianej logiki oraz etyki. Artykuł koncentruje się natomiast na wątkach antropologicznych, rozsianych $w$ różnego rodzaju tekstach filozofa. Pokazuje wiarę Mariana Przełęckiego w tkwiącą w człowieku dobroć, jego zainteresowanie wizją bytu ludzkiego nakreśloną przez Pascala, a także poglądy na kwestię determinizmu oraz stosunku ludzi do zwierząt.

Słowa kluczowe: antropologia, Marian Przełęcki, koncepcja człowieka Pascala

\section{Summary}

\section{Anthropological reflection developed by Marian Przełęcki}

Marian Przełęcki is primarily known for his scientific work on the broadly understood logic and ethics. However, the anthropological threads are found in various texts of this philosopher, therefore this article is an attempt to present and discuss them. M. Przełęcki expresses a strong faith in the goodness inherent in man, he is interested in the vision of human being developed by Pascal, as well as in views on determinism and the attitude of people to animals.

Key words: antropologia, Marian Przełęcki, Pascal's concept of man 